\title{
Characterization of Coatings Obtained by Dehydrated Paste-Pack Boriding Process Formed on AISI A36 Carbon and 304 Alloy Steels
}

\author{
M. Ortiz-Domínguez ${ }^{1 *}$, I. Morgado-González ${ }^{1}$, A. Cruz-Avilés ${ }^{1}$, A. Soto-García ${ }^{2}$, R. Trujillo-Sánchez ${ }^{2}$, \\ M. L. Moreno-González², G. Moreno-González², O. A. Gómez-Vagas² and J. Zuno-Silva ${ }^{1}$ \\ 1. Department of Mechanical Engineering, Universidad Autónoma del Estado de Hidalgo-Campus \\ Sahagún, Hidalgo, México. \\ 2. Research and Postgraduate Division, Instituto Tecnológico de Tlalnepantla, EdoMéx, México. \\ *Corresponding author:martin_ortiz@uaeh.edu.mx
}

Many operating difficulties and loss of production in industry arise through wear. Surface treatments can improve performance because the substrates improve their desired properties such as hardness, friction, wear resistance, and corrosion resistance. In particular, boriding is a thermochemical surface hardening method which can be applied to a wide range of ferrous, non-ferrous and cermet materials. The surface boride may be in the form of either a single phase or a double phase boride layer. Generally, the formation of a monophase $\left(\mathrm{Fe}_{2} \mathrm{~B}\right)$ with saw-tooth morphology is more desirable than a double-phase layer with $\mathrm{FeB}$ and $\mathrm{Fe}_{2} \mathrm{~B}$ for industrial applications. The boron-rich $\mathrm{FeB}$ phase containing approximately $16.23 \mathrm{wt} \% \mathrm{~B}$ is not desirable because $\mathrm{FeB}$ is more brittle than the iron sub-boride and $\mathrm{Fe}_{2} \mathrm{~B}$ phase which is containing $8.8 \mathrm{wt} \% \mathrm{~B}[1-3]$. In this study, the microstructure of the single phase layer $\left(\mathrm{Fe}_{2} \mathrm{~B}\right)$ and the double phase layer $\left(\mathrm{FeB}+\mathrm{Fe}_{2} \mathrm{~B}\right)$ have been investigated at $1123 \mathrm{~K}$ with exposure times of $4 \mathrm{~h}$ and $8 \mathrm{~h}$ by dehydrated paste-pack method on the surface of AISI A36 and 304 steels. Boriding heat treatment was carried out by using dehydrated paste-pack boriding method that is similar to pack carburizing process. Boriding mixture contains of $\mathrm{B}_{4} \mathrm{C}$ (active source of boron), $\mathrm{Na}_{3} \mathrm{AlF}_{6}$ (activator), SiC (inert filler), and $\mathrm{SiC}_{8} \mathrm{H}_{20} \mathrm{O}_{4}$ which is used to protect surfaces. All samples to be borided were packed in the powder mix and sealed in a stainless steel container (see Figure 1). Boriding experiment was performed in an electrical resistance furnace under atmospheric environment at $1123 \mathrm{~K}$ for 4 and $8 \mathrm{~h}$. Once the boriding treatment was finished the container was removed from the furnace and slowly cooled to room temperature. The hard samples were cross-sectioned and resin-embedded for traditional metallographic preparation, were grinded with $\mathrm{SiC}$ abrasive paper up to grit 2500. Afterwards, the samples were polished using a diamond suspension with particle size of $6 \mu \mathrm{m}$, finishing with particle size of $3 \mu \mathrm{m}$, then the polished samples were etched in a $2 \%$ nital solution to observe the boride layer depths formed on the surface of AISI A36 and 304 steels. The boride layer depths and morphology were analysed by Scanning Electron Microscopy (SEM), Energy Dispersive Spectroscopy (EDS) and X-ray diffraction (XRD) for the borided AISI A36 and 304 steels. Figure 2 shows the cross-sections of boride layers formed on the surface of AISI A36 and 304 steels at $1123 \mathrm{~K}$ for $4 \mathrm{~h}$ and $8 \mathrm{~h}$.). The formation of a double-phase layer $\left(\mathrm{FeB}+\mathrm{Fe}_{2} \mathrm{~B}\right)$ was revealed with a flat morphology (see Fig. 2a and Fig. 2b). This particular morphology is attributed to the presence of the alloying elements in the substrate of AISI 304 steel and can be explained by the existence of activated diffusion pathways in the $\mathrm{Fe}_{2} \mathrm{~B}$ and $\mathrm{FeB}$ crystal lattices. Likewise, the resultant microstructure of a single-phase layer $\left(\mathrm{Fe}_{2} \mathrm{~B}\right.$ only) layers looks very dense, compact and homogenous, with sawtooth morphology. This particular morphology is ascribed to the presence of carbon and alloying elements in AISI A36 (see Fig. 2c and Fig. 2d. It is known that the alloying elements modify the morphology of $\left(\mathrm{FeB} / \mathrm{Fe}_{2} \mathrm{~B}\right.$ and $\mathrm{Fe}_{2} \mathrm{~B} /$ substrate) interfaces and tend to concentrate at the tips of the boride needles by generating a flat morphology. The EDS analysis obtained by SEM at the $\left(\mathrm{FeB} / \mathrm{Fe}_{2} \mathrm{~B}\right)$ for the borided AISI 304 steel is shown in Fig. 3a and for the borided AISI A36 steel is shown in Fig. 3b. The results of XRD studies presented in Fig. 4a and Fig. 4b show the 
XRD pattern recorded on the surface of borided AISI A36 and 304 steels, respectively. They confirm that iron diboride $\left(\mathrm{Fe}_{2} \mathrm{~B}\right)$ on the surface of borided AISI A36 steel. Likewise, the diffraction peaks relative to the iron boride $(\mathrm{FeB})$ and the iron diboride $\left(\mathrm{Fe}_{2} \mathrm{~B}\right)$ are easily identified on the surface of borided AISI 304. These results demonstrate that the dehydrated paste-pack method applied to AISI A36 and 304 steels formed a single phase layer $\mathrm{Fe}_{2} \mathrm{~B}$ or a double phase layer $\left(\mathrm{FeB}+\mathrm{Fe}_{2} \mathrm{~B}\right)$ depending on the chemical composition.

References:

[1] A Graf von Matuschka in "Boronizing”, $1^{\text {st }}$ ed. Carl Hanser Verlag (Munich) p. 12.

[2] JR Davis in "Surface Hardening of Steels: Understanding the Basics", $1^{\text {st }}$ ed. (ASM, Ohio) p. 213.

[3] S Singhal, Thin Solid Films 45 (1977), p. 321.

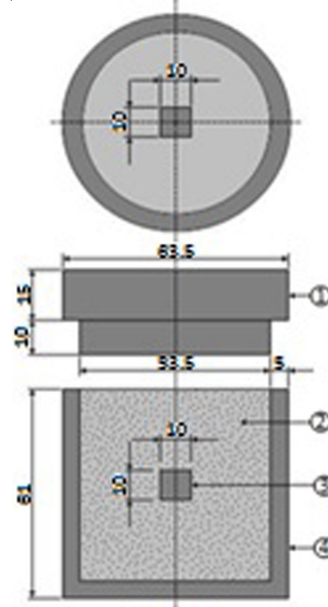

Fig. 1

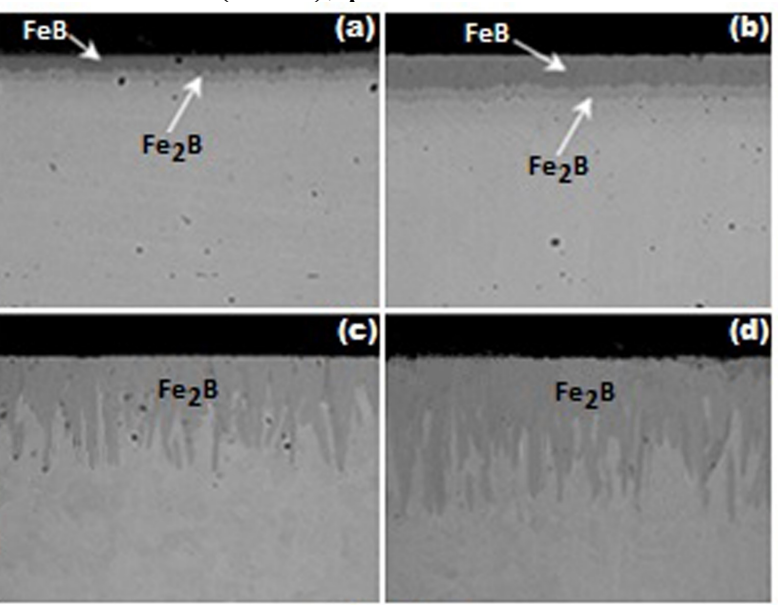

Fig. 2

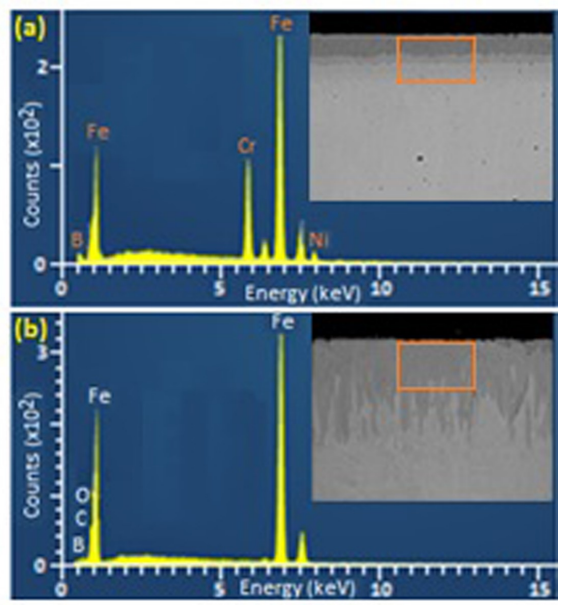

Fig. 3

Figure 1. Schematic view of the stainless steel AISI 316L container for the powder-pack boriding treatment; images (SEM) of cross-sections of borided: AISI 304 steel at $1123 \mathrm{~K}$ : (a) $4 \mathrm{~h}$ and (b) $8 \mathrm{~h}$; AISI A36 at $1123 \mathrm{~K}$ : (c) $4 \mathrm{~h}$ and (d) $8 \mathrm{~h}$ (Figure 2.) and EDS spectrum of borided samples at interfaces: (a) borided AISI 304 and (b) A36 steels at $1123 \mathrm{~K}$ for 8 hours of treatment (Figure 3.).

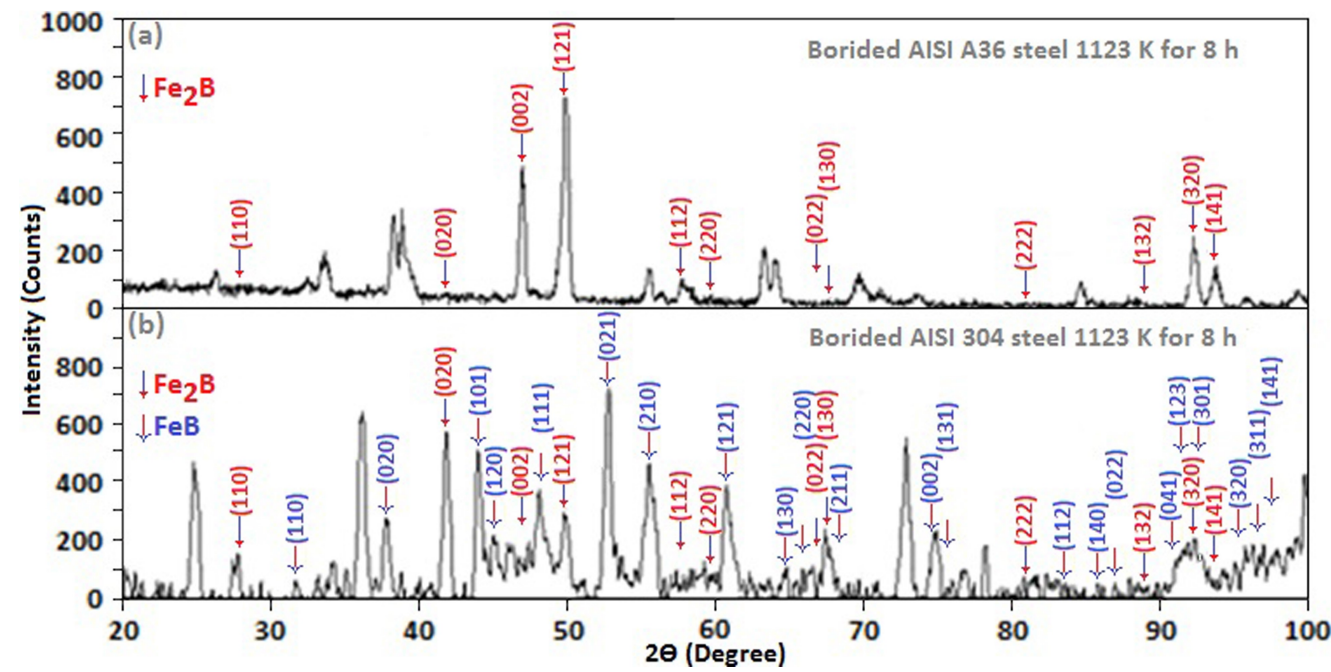

Figure 4. XRD diffraction patterns of: (a) borided AISI A36 and (b) 304 steels at $1123 \mathrm{~K}$ for 8 hours. 